\title{
Presumed Zika virus-related congenital brain malformations: the spectrum of CT and MRI findings in fetuses and newborns
}

\author{
Malformações congênitas do encéfalo presumivelmente relacionadas ao Zika vírus: \\ espectro de achados de RM e TC em fetos e neonatos \\ José Daniel Vieira de Castro', Licia Pacheco Pereiraํ., Daniel Aguiar Dias', Lindenberg Barbosa Aguiar', Joanira \\ Costa Nogueira Maia', Jesus Irajacy Fernandes da Costa ${ }^{1}$, Eveline Campos Monteiro de Castro², Francisco \\ Edson de Lucena Feitosa², Francisco Herlânio Costa Carvalho²
}

\begin{abstract}
The new epidemic of Zika virus infection raises grave concerns, especially with the increasingly-recognized link between emerging cases of microcephaly and this infectious disease. Besides small cranial dimensions, there are striking morphologic anomalies in the fetal brain. Key anomalies include cortical developmental malformations and a peculiar distribution of pathologic calcifications. These potentially indicate a new pattern of congenital central nervous system infection. Methods: Eight women underwent fetal MRI. Four infants also underwent postnatal CT. Five of the women underwent amniocentesis. Results: All neonates were born with microcephaly. On fetal MRI, ventriculomegaly, marked reduction of white matter thickness, severe sylvian fissure simplification, abnormal sulcation, and diffuse volumetric loss of cerebellar hemispheres were consistently seen. On postnatal CT, diffuse subcortical and basal ganglia calcifications were observed. The Zika virus was detected in two amniocenteses by polymerase chain reaction assays. Conclusion: We hope to assist the medical community in recognizing the spectrum of encephalic changes related to congenital Zika virus infection.
\end{abstract}

Keywords:Zika virus; microcephaly; tomography, X-ray computed; magnetic resonance imaging.

RESUMO

Os novos casos epidêmicos de infecção pelo vírus Zika suscitam grande preocupação, sobretudo com o crescente reconhecimento da ligação entre casos emergentes de microcefalia e esta doença infecciosa. Além da cabeça de pequenas dimensões, existem profundas alterações morfológicas no encéfalo fetal. Anomalias mais típicas incluem malformações do desenvolvimento cortical e uma distribuição peculiar de calcificações patológicas. Estes dados potencialmente indicam um novo padrão de infecção congênita do sistema nervoso central. Métodos: Oito mulheres foram submetidas a RM fetal. Quatro crianças também realizaram TC pós-natal. Cinco mulheres foram submetidas a amniocentese. Resultados: Todos os neonatos nasceram com microcefalia. Na RM fetal, ventriculomegalia, acentuada redução da espessura da substância branca, acentuada simplificação da fissura sylviana, sulcação anormal e redução volumétrica difusa dos hemisférios cerebelares foram constantes. Na TC pós-natal, calcificações difusas subcorticais e nos núcleos da base foram observadas. O vírus Zika foi detectado por PCR em duas amniocenteses. Conclusão: Esperamos dar suporte à comunidade médica em reconhecer este padrão de imagem potencialmente específico.

Palavras-chave: Zika vírus; microcefalia; tomografia computadorizada por raios X; imagem por ressonância magnética.

The Zika virus (ZIKV), a RNA virus of the flavivirus family', was first isolated in 1947 in Rhesus monkeys in a forest called Zika, in Uganda, Africa². Up until 2007, only a few cases of human infection with this virus were seen in Africa and Asia. Before that, its circulation was limited to monkeys. In Brazil, its transmission is by the Aedesaegypti and Aedes albopcuts ${ }^{3}$ mosquito. Brazil has coexisted with the Aedesaegypti mosquito, brought in from African ships, since the country's colonization. This species easily breeds in standing water. The tropical climate conditions, poor sanitation, and low education level provide an excellent means through which this virus perpetuates in Brazil ${ }^{4}$.

The first report of ZIKV infection in Brazil was in April $2015^{5}$. Clinically, the infection is similar to Dengue virus infection, a disease that has been present in the country for a long time. Headache, fever, body ache, fatigue, and skin spot

¿Universidade Federal do Ceará, Hospital Universitário Walter Cantídio, Setor de Radiologia, Fortaleza, CE, Brasil;

Universidade Federal do Ceará, Programa de pós-graduação em Saúde Pública, Departamento de Saúde Materno-Infantil, Fortaleza, CE, Brasil.

Correspondence: José Daniel Vieira de Castro;Avenida Professor Euclides César, 420;60177-200 Fortaleza CE, Brasil; E-mail: danielcastrorevisor@gmail.com Conflict of interest: There is no conflict of interest to declare.

Received 12 November 2016; Received in final form 15 January 2017; Accepted 10 July 2017. 
lesions are some of the representative signs and symptoms. In ZIKV infection, conjunctivitis can also occur6. Parallel to the appearance of ZIKV infection in Brazil, there was also an explosion of cases of microcephaly associated with congenital brain malformations, which also occurred in French Polynesia. In addition, the virus was found in the amniotic fluid, tissues, and blood of a baby with microcephaly who died in the Brazilian state of Ceará .

Although yet to be proven, both the Brazilian Ministry of Health and the World Health Organization admit the relationship between ZIKV and microcephaly because of the strong available epidemiological data. In 2014, there were 147 cases of microcephaly in Brazil ${ }^{8}$. From mid 2015 to late January 2016 there were 4, 783 suspected cases of microcephaly in the country ${ }^{9}$. Unfortunately, these numbers increase everyday. On February 1, 2016, the World Health Organization declared microcephaly, and other neurological disorders possibly associated with the ZIKV, an international public health emergency ${ }^{1}$.

At the birth of affected children in Brazil, microcephaly was defined as a head circumference measuring less than 32 cm (12. 5 inches) in term newborns, or below two standard deviations (SD) on the obstetric ultrasound ${ }^{10}$. Microcephaly can be divided into primary, when the brain is never formed normally, and secondary, in which the brain had its normal development halted at some point. Among secondary causes are infections caused by rubella, syphilis, cytomegalo virus, and herpes virus (STORCH) ${ }^{11}$. It is part of the prenatal program in Brazil to perform serological tests (IGG and IGM) in order to rule out these diseases during pregnancy (except for herpes virus).

Magnetic resonance imaging (MRI) is an excellent imaging method for assessing the central nervous system (CNS) of fetuses with suspected defects. The absence of ionizing radiation and the ability for greater tissue differentiation allows for a better study of the CNS, without the limitations caused by skull artifact or fetal position, making it an adjuvant method for ultrasound ${ }^{12,13}$.

The aim of this study is to describe the MRI findings of fetuses and newborns with microcephaly presumably caused by congenital ZIKV infection.

\section{METHODS}

This retrospective study was approved by our institutional review board and patient/parental consent was obtained. Patient characteristics are shown in Table 1. Eight women (mean age, 29.4 years; range, 19-41 years), mean gestational age, 31.2 weeks (28-38), with suspected fetal malformations on ultrasound possibly associated with the ZIKV, underwent fetal MRI at the University Hospital of the Universidade Federal do Ceará, during the Brazilian epidemic, between November 2015 and February 2016.
All patients reported a rash suggestive of a ZIKV infection in the first trimester. They were living in an epidemic area for the virus and/or had contact with family members or neighbors with the disease symptoms. They all had negative serology for STORCH. Amniocentesis was performed in five of the patients. All fetuses met the clinical-radiological criteria for presumed congenital ZIKV infection, as established by the protocols defined by the Brazilian Ministry of Health ${ }^{12}$, even without being tested for IgM antibodies to the virus, since the test was not yet routinely available. These criteria were also used in recently-published studies ${ }^{15,16,17,18,19}$. Four of the infants underwent a postnatal CT scan.

The following fetal biometric parameters were assessed on ultrasound: biparietal diameter and head circumference, according to the guidelines proposed by the International Society of Ultrasound in Obstetrics and Gynecology ${ }^{20}$. Mild microcephaly was defined as a fetal head circumference between 2 and 3 SD below the expected mean for gestational age. Severe microcephaly was defined as a fetal head circumference of $3 \mathrm{SD}$ below the expected mean value for gestational age ${ }^{21}$. If microcephaly was detected, a thorough ultrasound scan was performed to identify brain pathology such as midline-echo anomalies, intracranial calcifications, ventriculomegaly and/or extracranial malformations.

All the pregnant women had consultations with fetal medicine specialists and geneticists to investigate other possible causes of the CNS malformations, including detailed morphological ultrasound research for other congenital infections, previous use of teratogens, and family history of hereditary diseases. They were followed up in the institution through out the entire prenatal period.

\section{MR and CT Imaging}

Fetal MRI was performed with a 1.5 - T system (GE Healthcare, Chalfont St Giles, United Kingdom), using an abdomen coil. The MR protocol included fast imaging employing steady-state acquisition, repetition time msec/echo times msec, 3.8/1.7, section thickness $4 \mathrm{~mm}$, intersection gap $4.4 \mathrm{~mm}$, field of view 600-700 mm, matrix 512 x 512), T2-weighted single-shot fast spin-echo images (1240.54/87. 8, thickness $4 \mathrm{~mm}$, intersection gap $4.4 \mathrm{~mm}$, matrix $512 \times 512)$, T2* gradient-echo (467/15, thickness $4 \mathrm{~mm}$, intersection gap $4.4 \mathrm{~mm}$, matrix 256 x 256) and T1-weighted fast spoiled gradient-recalled acquisition in the steady state (100/2.5, thickness $4 \mathrm{~mm}$, intersection gap $4.4 \mathrm{~mm}$, matrix $512 \times 512$ ). We considered parenchymal calcifications at fetal MRI when marked T2-hypointense and T1-hyperintense and/or $\mathrm{T} 2 *$-hypointense foci were seen at the cortex, basal ganglia, periventricular regions and/or cerebellum. Non-enhanced brain CT scans were performed on a 64-section scanner (SOMATON Definition AS; Siemens Healthcare, Forchheim, Germany), using the spiral technique (total collimation width, 9.2; slice thickness, $1.0 \mathrm{~mm}$; pitch, 0.65). Brain parenchymal thickness was assessed with both CT and MRI at the level of the frontal horns of the lateral ventricles in the frontal regions. 


\begin{tabular}{|c|c|c|c|c|c|c|c|c|c|c|}
\hline \multirow[b]{2}{*}{$\begin{array}{l}\text { Patient } \\
\mathrm{N}^{\circ}\end{array}$} & \multirow[b]{2}{*}{$\begin{array}{l}\text { Mother's } \\
\text { age }\end{array}$} & \multirow{2}{*}{$\begin{array}{c}\text { GA at viral } \\
\text { infection } \\
\text { (weeks, referred } \\
\text { symptoms) }\end{array}$} & \multirow{2}{*}{$\begin{array}{l}\text { GA at MRI } \\
\text { diagnosis* } \\
\text { (weeks, } \\
\text { days) }\end{array}$} & \multirow[b]{2}{*}{$\begin{array}{c}\mathrm{HC}(\mathrm{cm}) \text { at } \\
\text { US; SD }\end{array}$} & \multirow[b]{2}{*}{$\begin{array}{l}\text { GA at birth } \\
\text { (weeks, } \\
\text { days) }\end{array}$} & \multirow[b]{2}{*}{$\begin{array}{c}\mathrm{HC}(\mathrm{cm}) \text { at } \\
\text { birth }\end{array}$} & \multicolumn{3}{|c|}{ Baby's serology (IgM) } & \multirow[b]{2}{*}{$\begin{array}{c}\text { ZIKA PCR } \\
\text { (Amniocentesis) }\end{array}$} \\
\hline & & & & & & & TORCH & Chikungunya & Dengue & \\
\hline 1 & 19 & 7-10 (fever) & 28 & $21.1 ;<4$ & 37.5 & 27 & $(-)$ & $(-)$ & $(-)$ & Detected*** \\
\hline 2 & 29 & 8 (fever, rash) & 31 & $24.0 ;<4$ & 40 & 24 & No data & No data & No data & No data \\
\hline 3 & 31 & $\begin{array}{c}\text { 8-10 (fever, } \\
\text { rash) }\end{array}$ & 31.5 & $20.0 ;<5$ & 38 & 20 & $(-)$ & $(-)$ & $(-)$ & Not detected \\
\hline 4 & 41 & 8 (fever, rash) & 37 & $27.7 ;<4$ & 38 & 27 & No data & No data & No data & No data \\
\hline 5 & 29 & $\begin{array}{l}\text { 1st trimester; } \\
\text { exact period } \\
\text { unknown (rash) }\end{array}$ & 38 & $27.5 ;<4$ & 38 & 29 & $(-)$ & $(-)$ & $(-)$ & Not detected \\
\hline 6 & 26 & $\begin{array}{l}\text { 1st trimester; } \\
\text { exact period } \\
\text { unknown (fever, } \\
\text { rash, joint pain) }\end{array}$ & 28.2 & $22.8 ;<5$ & 37.1 & 22.8 & $(-)$ & $(-)$ & $(-)$ & Not detected \\
\hline 7 & 20 & Asymptomatic & 38 & $27.3 ;<4 / 5$ & 38.6 & 27.3 & $(-)$ & $(-)$ & $(-)$ & Detected $* \star \star$ \\
\hline 8 & 35 & 8 (rash) & 28 & $23.4 ;<2^{\star *}$ & 39 & 24.6 & No data & No data & No data & No data \\
\hline
\end{tabular}

\section{RESULTS}

The ZIKV was detected in both amniocenteses by polymerase chain reaction test (PCR). All the neonates were born with microcephaly. The measurements of head circumference were on average $<-3 \mathrm{SD}$ from the mean for estimated gestational age (mean, 25.8 ranging from 20 to $29 \mathrm{~cm}$ ) (Table 1). The deliveries occurred at a mean gestational age of 38 weeks (38-40); newborns had a mean weight of 2, $695 \mathrm{~g}$ and a first minute Apgar of 8.

Ultrasound demonstrated reduced brain volume and ventriculomegaly in all cases; supratentorial parenchymal calcifications were depicted in five patients and cerebellar hypoplasia was seen in two patients. Extracranial abnormalities such as clubfoot, nuchal skin wrinkling, and intrauterine growth restriction were seen in two patients (Table 2). The earliest abnormalities depicted on ultrasound in our series were ventriculomegaly at 22 weeks and microcephaly at 26 weeks (Patient 8) - all other abnormalities were seen after the $28^{\text {th }}$ week of gestation.

On fetal MRI, there was ventriculomegaly, marked reduction of white matter thickness, severe sylvian fissure simplification (grade II, Knaap et al. ${ }^{13}$ classification) and abnormal sulcation, with predominance of pachygyria (Figures 1, 2, 3 and 4). There was also diffuse volumetric loss of cerebellar hemispheres (Figures 1D, 2B and 2C), brainstem hypoplasia (Figure 1A), subependymal occipital pseudocysts (Figure 5) and hypogenesis of the corpus callosum (Figure 6A). Focal calcifications was depicted on $\mathrm{T}_{2} *$ and $\mathrm{T} 1$ in two patients (Figure 4). Occipital pseudocysts were seen in four patients (Table 2).

The CT studies performed on four newborns showed decreased cerebral volume with ventriculomegaly and reduced parenchymal thickness, calcifications seen predominantly in the basal ganglia and the junction between cortical and subcortical white matter, and cerebral development malformations, including opercular dysplasia, pachygyria, lissencephaly and polymicrogyria (Table 3; Figure 6).

\section{DISCUSSION}

We have described the MRI findings of brain abnormalities in eight fetuses with presumed ZIKV-related congenital infection, of whom two tested positive for the virus, confirmed by PCR in the amniotic fluid. Even though not all cases were serologically confirmed, they met the protocol criteria for congenital infection presumably associated with the ZIKV as proposed by the Brazilian Ministry of Health ${ }^{14}$, which included 1) reported symptoms of the disease; 2) mothers who were living in an epidemic region; and 3) mothers who had negative serology for other CNS infections (TORCH). Incomplete serological confirmation was due to the unavailability of serological tests at the time of the diagnosis of the reported cases herein, as well as the difficulty of performing PCR and virus detection by this technique during the short period of viremia ${ }^{22}$. Other authors have also considered the same criteria in the presentation of their results ${ }^{15,16,19}$.

Brain changes caused by infectious agents during pregnancy differ from those that occur in children and adults because they occur during nervous tissue development. Manifestations of these infections will differ depending on the time when they occur and are less related to the virulence of the agent. Thus, in general, infections during the first two trimesters will result in congenital malformations, while those occurring in the third trimester will result in destructive lesions ${ }^{23}$.

The term TORCH is an acronym created to denote Toxoplasma gondii, rubeolla, cytomegalovirus and herpes viruses, and emphasizes these agents as a major cause of 


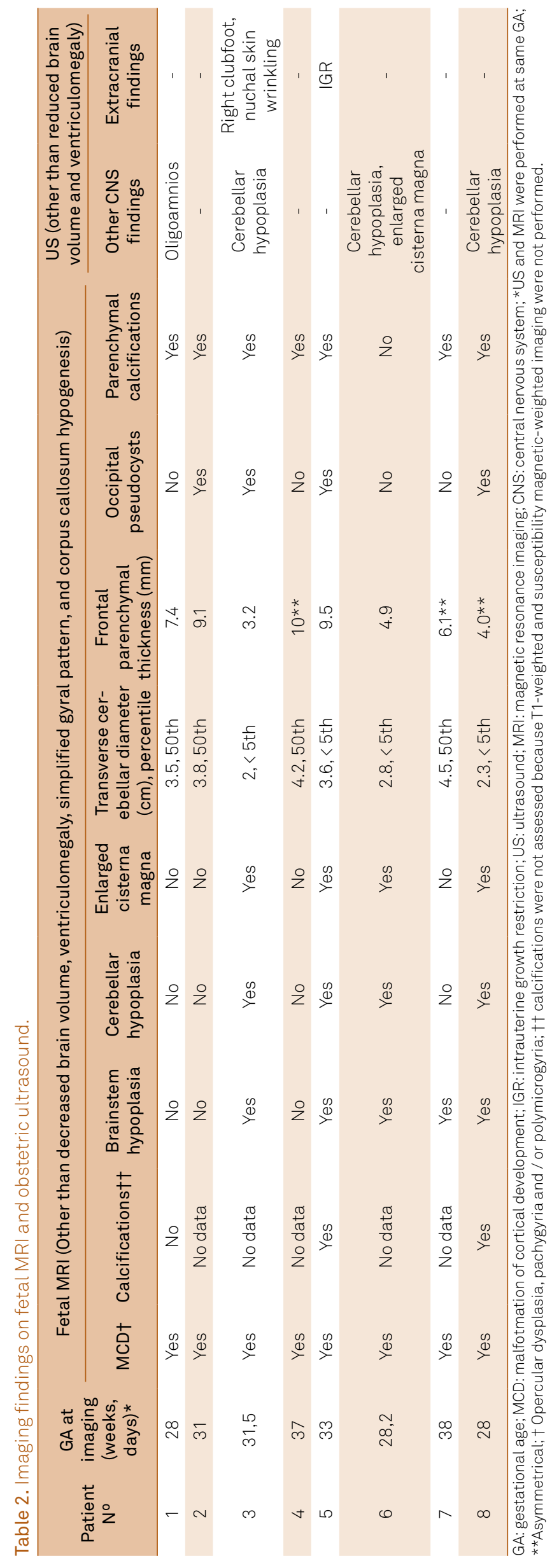

perinatal and congenital infections in humans. These agents remain the main causative factor of permanent damage to CNS, despite advances in vaccines and antiviral therapies. In addition to these agents, other less common viruses include lymphocytic choriomeningitis virus, parechovirus, and varicela-zoster virus ${ }^{23}$. All of these agents can cause irreversible damage to the CNS, the aspects of which can be very similar to each other, often making impossible the etiological diagnosis exclusively by imaging. The most common changes are microcephaly, ventriculomegaly, neuronal migration abnormalities, white matter changes, and abnormal CNS calcifications.

The alterations found in the fetuses and infants with suspected congenital ZIKV infection described herein demonstrated very similar patterns of change to those described in the TORCH syndrome with lissencephaly, sulcation abnormalities (including polymicrogyria and pachygyria), ventriculomegaly, and cerebral calcifications. The distribution of calcifications (basal ganglia, periventricular, and in the cortical and subcortical white matter junctions) seen in our patients is similar to the pattern described in cytomegalovirus infection, although the latter more commonly affects the periventricular region and the former the cortical and subcortical white matter junctions ${ }^{15}$, 24 . The only available methodology at the time of examination for a presumptive diagnosis of ZIKV infection was the negativity of serology for those agents already known, besides the positive epidemiological history of rash during pregnancy.

Our findings were consistent with the recently-published case series by Aragao et al. ${ }^{15}$, who described postnatal CT and MR findings in 23 children with presumed ZIKV infection. Besides the similar pattern of distribution of calcifications described here, malformation of cortical development with predominance of pachygyria or polymicrogyriain the frontal lobes and delayed myelination were seen. As well, Guillemette-Arturet al. ${ }^{25}$ recently reported very similar findings in a three-patient series using fetal MRI, including subependymal pseudocysts.

Although ocular findings were described in infants with microcephaly due to vertical ZIKV infection, particularly affecting the macular region, these ophthalmic alterations were not expressed on MRI or $\mathrm{CT}^{26}$.

Mlakaret al. ${ }^{27}$ recently published a case report describing the termination of pregnancy due to similarly severe brain malformations described herein. The ZIKV was isolated in brain parenchyma with absence in other fetal tissues, thereby demonstrating the neurotropism of this virus. This author also performed genetic sequencing of the virus and found similarity of the circulating viral strains in Brazil to those in Asia.

The possible relationship of ZIKV infection during pregnancy and the aforementioned CNS changes gives rise to great concern for global public health, as this virus presently does not have any effective treatment. Moreover, the spread of the mosquito vector in all parts of Brazil, and other countries in Latin America, Africa, Asia and Oceania, raises the possibility 

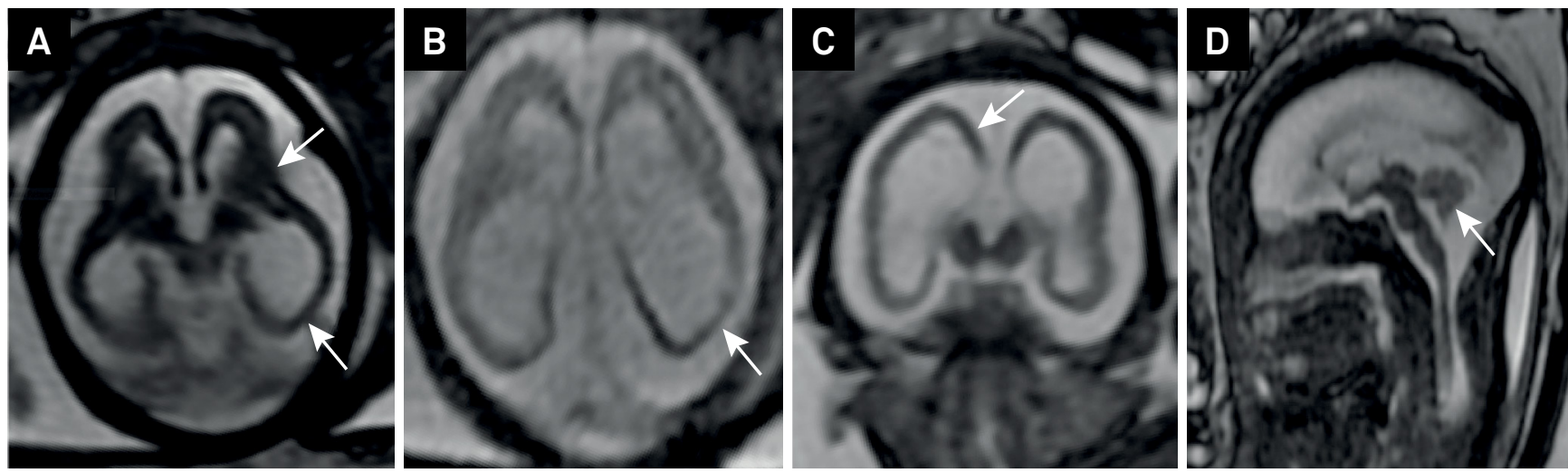

Figure 1. MR images of Patient 6 at 28.2 weeks of gestation (A, C, and D, fast imaging employing steady-state acquisition on axial, coronal and sagittal planes; B, T2-weighted single-shot fast spin-echo image on axial plane) demonstrating microcephaly and bilateral ventriculomegaly with marked reduction of white matter thickness, simplified gyri with shallow sylvian fissures (arrows in $\mathrm{A}-\mathrm{C}$ ) and cerebellar hypoplasia (arrow in D). Enlarged cisterna magna and brainstem hypoplasia are also noticed.
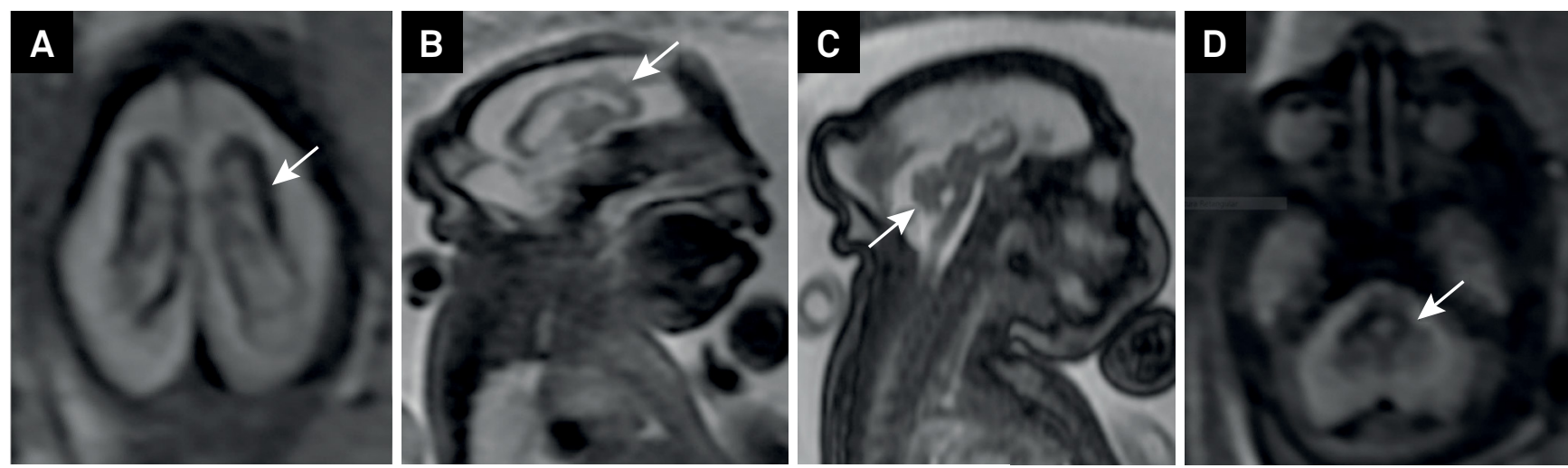

Figure 2. MR images of Patient 3 at 31.5 weeks of gestation (A, axial T2-weighted single-shot fast spin-echo image and fast imaging employing steady-state acquisition on axial, B, and sagittal planes, C and D). There is severe microcephaly, ventriculomegaly, and simplified gyral pattern with pachygyria (arrows in A and B). Brainstem hypoplasia, enlarged cisterna magna, and cerebellar hypoplasia (arrows in C and D) can also be seen.
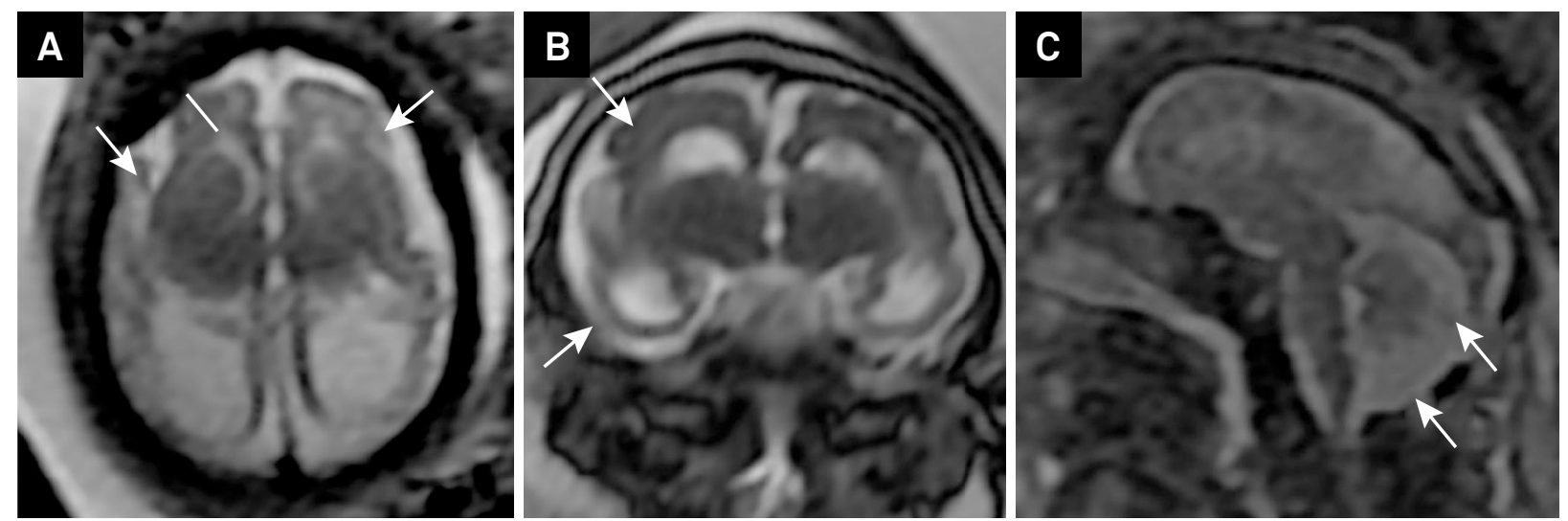

Figure 3. Patients with ZIKV detected by PCR in the amniotic fluid. MR images of Patient 7 at 38 weeks of gestation (A, T2-weighted single-shot fast spin-echo image on axial and B, fast imaging employing steady-state acquisition on axial plane) and of Patient 1 at 28 weeks of gestation (C, T2-weighted single-shot fast spin-echo image on coronal plane). Reduced parenchymal thickness, ventriculomegaly, opercular dysplasia, and simplified gyral pattern with pachygyria are consistently seen (arrows in A and B). The vermian size is within the normal range for the gestational age; enlarged cisterna magna is noticed (arrows in C). Figure A shows the location where the frontal parenchymal thickness was measured, at the level of the frontal horn of the lateral ventricle. 

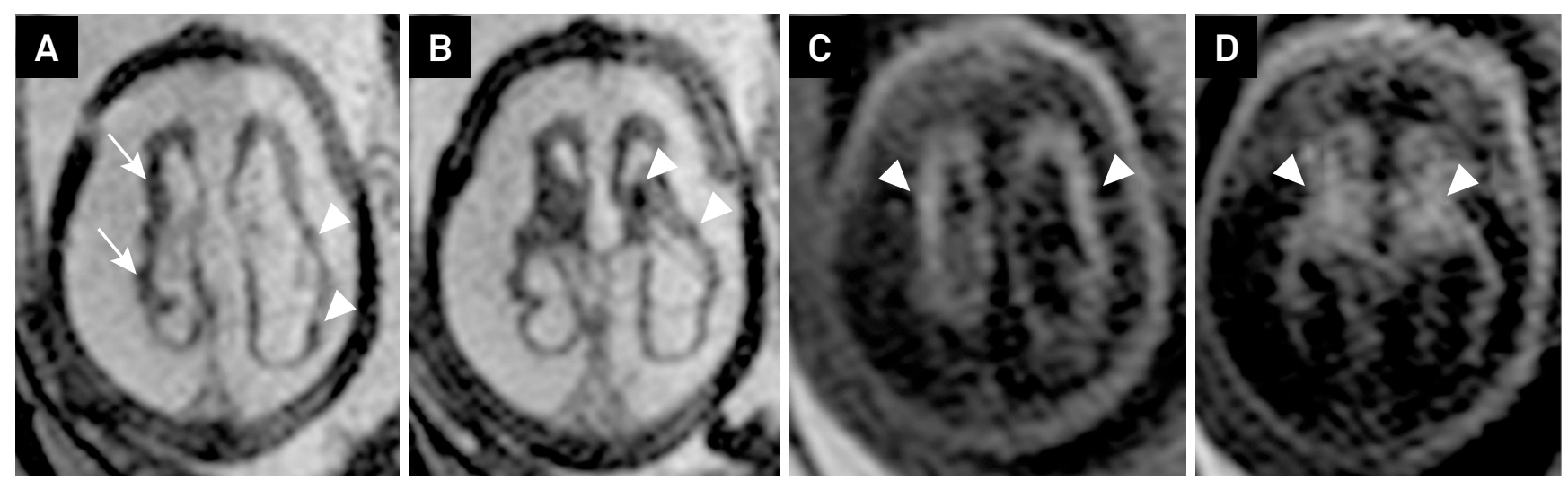

Figure 4. MR images of Patient 8 at 28 weeks of gestation ( $A$ and B, T2-weighted single-shot fast spin-echo images on axial and sagittal planes, $C$ and D, T1-weighted images on axial plane) demonstrating microcephaly and bilateral asymmetrical ventriculomegaly. The cortex is irregular (arrows in A) suggesting polymicrogyria. The marked T2-hypointense and T1-hyperintense foci (arrowheads) of the cortex and basal ganglia are consistent with calcifications.
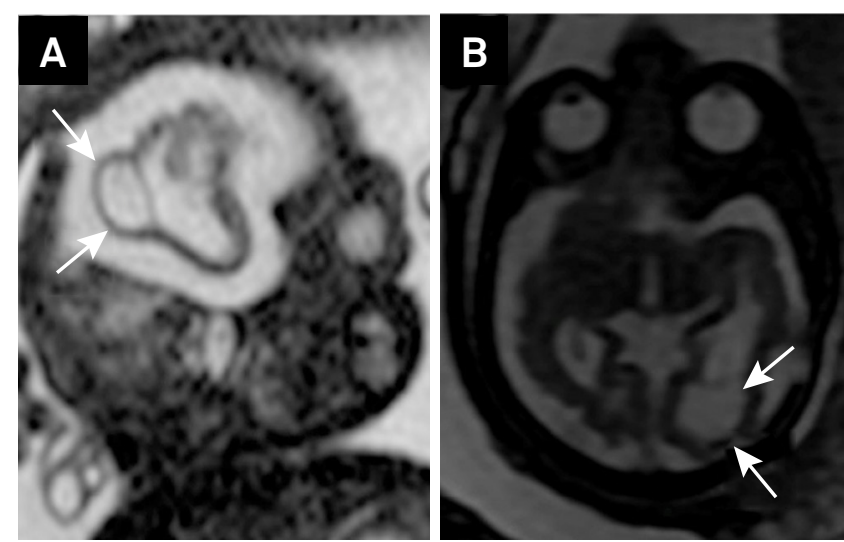

Figure 5. MR images of Patient 8 (A, T2-weighted single-shot fast spin-echo images on sagittal plane) and Patient 2 (B, fast imaging employing steady-state acquisition on axial plane) at 28 and 31 weeks of gestation, respectively, demonstrating the subependymal occipital pseudocysts (arrows).

of a pandemic of congenital brain malformations and microcephaly with incalculable social and economic consequences.

While evidence of the association between the ZIKV and fetal brain abnormalities continues to grow, the period of infection during fetal development that may be susceptible to viral pathogenesis, and how it affects the appearance of brain abnormalities on imaging, are currently poorly understood. Reported evidence suggests a predilection of the ZIKV strain for human neural lineage cells. Histopathological findings in a mid gestational fetus included loss of intermediately-differentiated postmigratory neurons through an apoptotic mechanism, with preservation of more differentiated neurons in the basal ganglia, limbic region, dorsal spinal cord and germinal matrix ${ }^{28}$. A recent study has also shown a high rate of ZIKV infection in cortical neural progenitor cells, but not in embryonic or pluripotent stem cells ${ }^{29}$.

When the outbreak of the Brazilian epidemic occurred, ZIKV laboratory assays were not routinely available; thus, unfortunately, they were not performed in our patients. However, even at present, the clinical presentation of ZIKV infection can be misleading - it is estimated that $80 \%$ of ZIKV infections are asymptomatic ${ }^{28}$, being difficult to diagnose and distinguish from other viral infections ${ }^{30}$. The gold standard for identification of viral infections is the isolation of the etiological agent in culture, but it requires a high viral load and the right timing for sample collection, since the ZIKV remains circulating in blood for up to five days after the onset of symptoms. A precise and fast diagnosis of an ongoing infection can be achieved by performing a reverse transcription polymerase chain reaction. ZIKV RNA and viable viruses have also been detected in urine, saliva, semen and vaginal secretion for up to 30 days, making these specimens an alternative for late diagnosis ${ }^{30,31}$.

We have demonstrated fetal MRI brain abnormalities of the recently-named congenital Zika syndrome, providing an association of the presumed affected cases with the traditional findings of CNS infections. The association of microcephaly, ventriculomegaly, a simplified gyral pattern, and calcification distributed predominantly in the cortical and subcortical white matter can be demonstrated in fetal MRI, which shows better details than the findings from an ultrasound. These abnormalities are highly suggestive of ZIKV infection, when epidemiological criteria are met, thus allowing a more accurate diagnosis of CNS damage. In addition, because it does not use ionizing radiation and provides a greater tissue differentiation than ultrasound, MRI is preferably used to better evaluate CNS disorders. Future research should focus on the description of serologically-confirmed cases in which changes can be specifically linked to ZIKV. Moreover, there likely will be differences described in individual patients that may be associated with possible changes in clinical presentations and development of these children, most of whom are very seriously affected. We also need to know how these changes will evolve over the long term. 

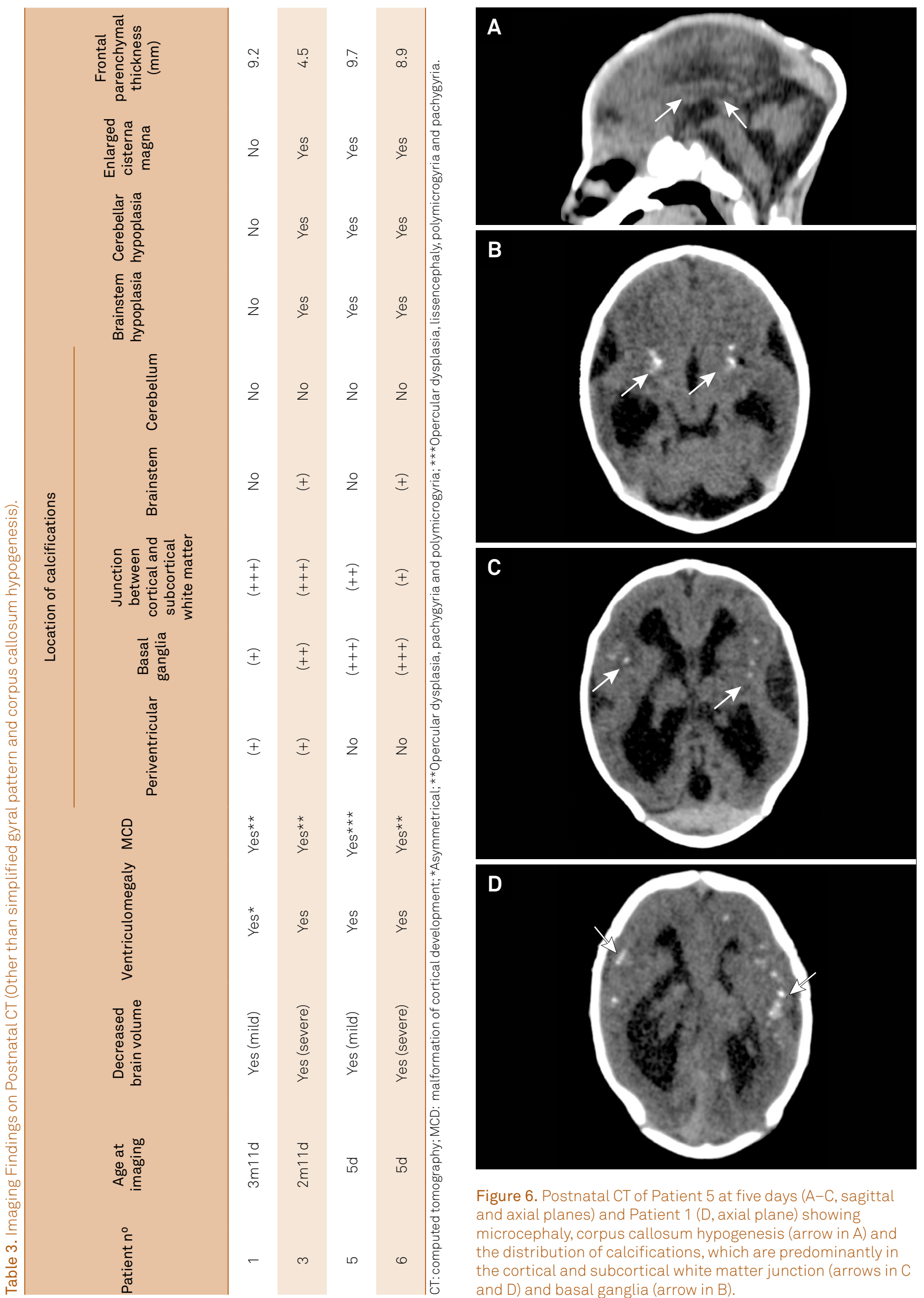

Figure 6. Postnatal CT of Patient 5 at five days (A-C, sagittal and axial planes) and Patient 1 (D, axial plane) showing microcephaly, corpus callosum hypogenesis (arrow in A) and the distribution of calcifications, which are predominantly in the cortical and subcortical white matter junction (arrows in C and D) and basal ganglia (arrow in B). 
1. World Health Organization - WHO. WHO statement on the first meeting of the International Health Regulations (2005) (IHR 2005) Emergency Committee on Zika virus and observed increase in neurological disorders and neonatal malformations. Geneva: World Health Organization; 2016.

2. Heang V, Yasuda CY, Sovann L, Haddow AD, Rosa APT, Tesh RB et al. Zika virus infection, Cambodia, 2010. Emerg Infect Dis. 2012;18(2):349-51. https://doi.org/10.3201/eid1802.111224

3. Buathong R, Hermann L, Thaisomboonsuk B, Rutvisuttinunt W, Klungthong C, Chinnawirotpisan P et al. Detection of Zika Virus Infection in Thailand, 2012-2014. Am J Trop Med Hyg. 2015;93(2):380-3. https://doi.org/10.4269/ajtmh.15-0022

4. Fauci AS, Morens DM. Zika virus in the Americas: yet another arbovirus threat. N Engl J Med. 2016;374(7):601-4. https://doi.org/10.1056/NEJMp1600297

5. De Noronha L,Zanluca C, Azevedo MLV et al.Zika virus damages the human placental barrier and presents marked fetal neurotropism. Memórias do Instituto Oswaldo Cruz. 2016;111(5):287-293.

6. Duffy MR, Chen TH, Hancock WT, Powers AM, Kool JL, Lanciotti RS et al. Zika virus outbreak on Yap Island, Federated States of Micronesia. N Engl J Med. 2009;360(24):2536-43. https://doi.org/10.1056/NEJMoa0805715

7. Musso, D., Baud, D.Zika virus: time to move from case reports to case control. Lan- cet Infect. Dis. 2016; 16: 620-621.

8. Victora CG, Schuler-Faccini L, Matijasevich A, Ribeiro E, Pessoa A, Barros FC. Microcephaly in Brazil: how to interpret reported numbers? Lancet. 2016;387(10019):621-4. https://doi.org/10.1016/S0140-6736(16)00273-7

9. Centro de Operações de Emergências em Saúde Pública sobre Microcefalias COES-Microcefalias. Monitoramento dos casos de microcefalia no Brasil. Informe Epidemiológico, 2016 [cited 2017 July 14];(11). Available from: http://combateaedes.saude. gov.br/images/pdf/informe-epidemiologico-11-2016.pdf

10. Ministério da Saúde (BR). Secretaria de Vigilância em Saúde. Protocolo de vigilância e resposta à ocorrência de microcefalia relacionada à infecção pelo vírus Zika. Brasília, DF: Secretaria de Vigilância em Saúde; 2015.

11. Adachi Y, Poduri A, Kawaguch A, Yoon G, Salih MA, Yamashita Fet al. Congenital microcephalywith a simplifiedgyralpattern: associatedfindingsandtheirsignificance. AJNR Am J Neuroradiol. 2011;32(6):1123-9. https://doi.org/10.3174/ajnr.A2440

12. Ghai S, Fong KW, Toi A, Chitayat D, Pantazi S, Blaser S. Prenatal US and MR imaging findings of lissencephaly: review of fetal cerebral sulcal development. Radiographics. 2006;26(2):389-405. https://doi.org/10.1148/rg.262055059

13. Knaap MS, Wezel-Meijler G, Barth PG, Barkhof F, Adèr HJ, ValkJ. Normal gyration and sulcation in preterm and term neonates: appearance on MR images. Radiology. 1996;200(2):389-96. https://doi.org/10.1148/radiology.200.2.8685331

14. Ministério da Saúde (BR). Secretaria de Vigilância em Saúde. Protocolo de vigilância e resposta à ocorrência de microcefalia e/ou alterações do sistema nervoso central (SNC). Brasília, DF: Secretaria de Vigilância em Saúde; 2016.

15. Aragao MFV, Linden V, Brainer-Lima AM, Coeli RR, Rocha MA, Sobral da Silva P et al. Clinical features and neuroimaging (CT and MRI) findings in presumed Zika virus related congenital infection and microcephaly: retrospective case series study. BMJ. 2016;353:11901. https://doi.org/10.1136/bmj.i1901
16. Oliveira-Szejnfeld PS, Levine D, Melo AS, Amorim MM, Batista AG, Chimelli L et al.Congenital brain abnormalities and Zika virus: what the radiologist can expect to see prenatally and postnatally. Radiology. 2016;281(1):203-18. https://doi.org/10.1148/radiol.2016161584

17. Araujo AQ, Silva MT, Araujo AP. Zika virus-associated neurological disorders: a review. Brain. 2016;139(Pt 8):2122-30. https://doi.org/10.1093/brain/aww158

18. Carvalho FH, Cordeiro KM, Peixoto AB, Tonni G, Moron AF, Feitosa FE et al. Associated ultrasonographic findings in fetuses with microcephaly because of suspected Zika virus (Z|KV) infection during pregnancy. PrenatalDiagn. 2016;36(9):882-7. https://doi.org/10.1002/pd.4882

19. Linden V, Rolim Filho EL, Lins OG, Linden A, Aragão MF, Brainer-Lima AM et al. Congenital Zikasyndromewitharthrogryposis: retrospective case series study. BMJ (Clinicalresearched). 2016;354:i3899. https://doi.org/10.1136/bmj.i3899

20. Salomon LJ, Alfirevic Z, Berghella V, Bilardo C, Hernandez-Andrade E, Johnsen SL et al. Practice guidelines for performance of the routine mid-trimester fetal ultrasound scan. Ultrasound Obstet Gynecol. 2011;37(1):116-26. https://doi.org/10.1002/uog.8831

21. International Society of Ultrasound in Obstetrics \& Gynecology Education Committee. Sonographic examination of the fetal central nervous system: guidelines for performing the 'basic examination' and the 'fetal neurosonogram. UltrasoundObstetGynecol. 2007;29(1):109-16. https://doi.org/10.1002/uog.3909

22. Ministério da Saúde (BR). Secretaria de Atenção à Saude, Secretaria de Vigilância em Saúde. Orientações integradas de vigilância e atenção à saúde no âmbito da Emergência de Saúde Pública de Importância Nacional. Brasília, DF: Secretaria de Vigilância em Saúde; 2016.

23. Bale JF Jr. Fetal infections and brain development. ClinPerinatol. 2009;36(3):639-53. https://doi.org/10.1016/j.clp.2009.06.005

24. Fink KR, Thapa MM, Ishak GE, Pruthi S. Neuroimaging of pediatric central nervous system cytomegalovirus infection. Radiographics. 2010;30(7):1779-96. https://doi.org/10.1148/rg.307105043

25. Guillemette-Artur P, Besnard M, Eyrolle-Guignot D, Jouannic J-M, Garel C. Prenatal brain MRI of fetuses with Zika virus infection. Pediatr Radiol. 2016;46(7):1032-9. https://doi.org/10.1007/s00247-016-3619-6

26. Ventura CV, Maia M, Bravo-Filho V, Góis AL, Belfort R, Jr. Zika virus in Brazil and macular atrophy in a child with microcephaly. Lancet. 2016;387(10015):228. https://doi.org/10.1016/S0140-6736(16)00006-4

27. Mlakar J, Korva M, Tul N, Popović M, Poljšak-Prijatelj M, Mraz J et al. Zika Virus Associated with Microcephaly. N Engl J Med. 2016;374(10):951-8. https://doi.org/10.1056/NEJMoa1600651

28. Driggers RW, Ho C-Y, Korhonen EM, Kuivanen S, Jääskeläinen AJ, Smura T et al. Zika Virus Infection with Prolonged Maternal Viremia and Fetal Brain Abnormalities. N Engl J Med. 2016;374(22):2142-51. https://doi.org/10.1056/NEJMoa1601824

29. Tang H, Hammack C, Ogden SC, Wen Z, Qian X, Li Y et al. Zika Virus Infects human cortical neural progenitors and attenuates their growth. Cell Stem Cell. 2016;18(5):587-90. https://doi.org/10.1016/j.stem.2016.02.016

30. Ribeiro LS, Marques RE, Jesus AMR, Almeida RP, Teixeira MM. Zika crisis in Brazil: challenges in research and development. CurrOpinVirol. 2016;18:76-81. https://doi.org/10.1016/j.coviro.2016.04.002

31. Rudolph KE, Lessler J, Moloney RM, Kmush B, Cummings DAT. Incubation periods of mosquito-borne viral infections: a systematic review. Am J Trop Med Hyg. 2014;90(5):882-91. https://doi.org/10.4269/ajtmh.13-0403 